\title{
Insight Into Late Wilting Disease of Cucumber Demonstrates the Complexity of the Phenomenon in Fluctuating Environments
}

\author{
Amit M. Philosoph, ${ }^{1,2}$ Aviv Dombrovsky, ${ }^{1}$ Yigal Elad, ${ }^{1}$ Amnon Koren, ${ }^{3}$ and Omer Frenkel ${ }^{1, \dagger}$ \\ ${ }^{1}$ Department of Plant Pathology and Weed Sciences, Agricultural Research Organization, The Volcani Center, Rishon Lezion \\ 7528809, Israel \\ ${ }^{2}$ The Robert H. Smith Faculty of Agriculture, Food and Environment, The Levi Eshkol School of Agriculture, The Hebrew Uni- \\ versity of Jerusalem, Rehovot 761001, Israel \\ ${ }^{3}$ Hishtil Nurseries, Nehalim, Israel
}

Abstract

\begin{abstract}
Some diseases are caused by coinfection of several pathogens in the same plant. However, studies on the complexity of these coinfection events under different environmental conditions are scarce. Our ongoing research involves late wilting disease of cucumber caused by coinfection of $\mathrm{Cu}$ cumber green mottle mosaic virus (CGMMV) and Pythium spp. We specifically investigated the role of various temperatures $\left(18,25,32^{\circ} \mathrm{C}\right)$ on the coinfection by CGMMV and two predominant Pythium species occurring in cucumber greenhouses under Middle Eastern climatic conditions. During the summer months, Pythium aphanidermatum was most common, whereas $P$. spinosum predominated during the winter-spring period. $P$. aphanidermatum preferred higher temperatures while $P$. spinosum preferred low temperatures and caused very low levels of disease at $32^{\circ} \mathrm{C}$ when the 6-day-old seedlings were infected with $P$. spinosum alone. Nevertheless, after applying a later coinfection with CGMMV
\end{abstract}

on the 14-day-old plants, a synergistic effect was detected for both Pythium species at optimal and suboptimal temperatures, with $P$. spinosum causing high mortality incidence even at $32^{\circ} \mathrm{C}$. The symptoms caused by CGMMV infection appeared earlier as the temperature increased. However, within each temperature, no significant influence of the combined infection was detected. Our results demonstrate the complexity of coinfection in changing environmental conditions and indicate its involvement in disease development and severity as compared with infection by each of the pathogens alone.

Keywords: damping-off, greenhouse, minor pathogen, multiple infection, soilborne pathogen, synergistic effect, Tobamovirus, oomycetes, vegetables, epidemiology, disease development and spread, disease management, viruses and viroids
Studies on plant diseases commonly refer to a single pathogen interacting with a single host plant. However, the important role of pathogens coinfecting the same host plant has been recognized in intra-kingdom as well as cross-kingdom interactions (Lamichhane and Venturi 2015; Tollenaere et al. 2017). These complex multispecies interactions, existing in the wild and in agroecosystems, may result in diverse epidemiological outcomes, including antagonistic and synergistic effects (Abdullah et al. 2017; Ataga et al. 1999; Tollenaere et al. 2017). Although an increasing number of studies recognizes the importance of these complexes, the interaction of such pathosystems with environmental conditions is still poorly understood (Marçais et al. 2017).

One such system involves the combined infection of Cucumber green mottle mosaic virus (CGMMV) and Pythium spp. that causes extensive collapses in mature greenhouse cucumbers (Philosoph et al. 2018). CGMMV was first described in 1935 (Ainsworth 1935) and belongs to the genus Tobamovirus, family Virgaviridae (Adams et al. 2009). It has been reported in Japan, Israel, Greece, and China (Antignus et al. 1990; Inoue 1967; Varveri et al. 2002;

${ }^{\dagger}$ Corresponding author: O. Frenkel; omerf@ volcani.agri.gov.il

Funding: The research was funded by The Chief Scientist of the Ministry of Agriculture and Rural Development, Israel. Project no 1321925. A. M. Philosoph is a recipient of the Yair Guron Fund. Contribution from the Agricultural Research Organization, The Volcani Center, Rishon Lezion, Israel. Contribution number 585/18.

*The $\boldsymbol{e}$-Xtra logo stands for "electronic extra" and indicates that three supplementary figures and three supplementary tables are published online.

The author(s) declare no conflict of interest.

Accepted for publication 18 May 2019.

(C) 2019 The American Phytopathological Society
Zhang et al. 2009) and more recently in Canada (Ling et al. 2014), California, U.S.A. (Tian et al. 2014), and Northern Territory, Australia (Tesoriero et al. 2015). CGMMV is considered a major pathogen of cucurbits worldwide (Dombrovsky et al. 2017). CGMMV's natural hosts include melon (Cucumis melo), watermelon (Citrullus lanatus), and cucumber (Cucumis sativus) (Lovisolo 1980). The highly stable viral particles can persist in CGMMV-contaminated seeds (Liu et al. 2014; Reingold et al. 2015), contaminated soil from a previous growing cycle (Reingold et al. 2016), and wild vegetation (Antignus et al. 1990). The virus spreads by direct mechanical contact with a range of contaminated sources, including seeds, propagation stock materials, and soil (Choi 2001; Wu et al. 2011). Typical symptoms of CGMMV in cucurbits include mottle and mosaic patterning of infected leaves and fruit distortions (Choi 2001; Lee 1996), often resulting in reduced yield and lower market value (Dombrovsky et al. 2017; Nontajak et al. 2014; Park et al. 2005).

In the last decade, the phenomenon of late wilting has increased in trellised cucumber greenhouses during CGMMV epidemics, resulting in extensive collapse and growth inhibition of plants more than 3 weeks after transplanting (Antignus et al. 2001; Philosoph et al. 2018). Similar phenomena have been reported in different countries including Nigeria (Ayo-John et al. 2014) and Norway (Sundheim et al. 2008). In Israel, the emerging wilting phenomenon that leads to the collapse of plants appears mostly in defined patches in greenhouses, often accompanied by visible damage to the lower stem tissue, and were demonstrated to be tightly linked with coinfection by Pythium spp. (Philosoph et al. 2018). Moreover, in the aforementioned study, there was almost no collapse of plants that were infected with CGMMV alone. These results led to the understanding that the collapse is caused by the interaction between these two pathogens.

The genus Pythium includes major pathogens of cucumber (BenYephet and Nelson 1999; Zitter et al. 1996), and can cause up to 75\% mortality during the first 2 weeks after transplanting (Al-Sadi et al. 2007, 2008). Plant-pathogenic Pythium species may cause diverse disease symptoms (Coffua et al. 2016; Hendrix and Campbell 
1973; Schroeder et al. 2013), ranging from symptomless to severe damping-off and root rot, depending on the host, environmental conditions, and plant age (Martin and Loper 2010). These pathogens may also colonize mature hosts, including cucumber plants, where symptoms include minor root rot and growth retardation. However, some studies suggest that with additional stress, some Pythium spp. may result in extensive collapse in infected plots (Al-Sadi et al. 2010) including viral infection stress (Nitzany 1966; Philosoph et al. 2018).

In recent years, the question of how coinfection may affect disease dynamics has gained increased recognition (Marçais et al. 2017). One of the fields that needs further studies is the role of environmental effects on the combined infection process. Climatic conditions and especially temperature may have a strong impact on the outcome of infection and pathogen populations, but very little is known about their relative importance during the coinfection process (Marçais et al. 2017; Vaumourin and Laine 2018).

Our previous study showed that two major species of Pythium are commonly isolated from collapsed mature plants coinfected with CGMMV (Philosoph et al. 2018). The first, Pythium spinosum was used to demonstrate the late wilting phenomena under controlled environment at room temperature $\left(24^{\circ} \mathrm{C}\right)$ and is known from other areas for causing damage at mild temperatures (Al-Sadi et al. 2007; Gherbawy and Abdelzaher 2002). Additionally, P. aphanidermatum was also detected in collapsed coinfected plants and is most common worldwide under much warmer conditions (temperatures as high as $30^{\circ} \mathrm{C}$ [Al-Sadi et al. 2007; Watanabe et al. 2008]). This provides a case study in which two different species of Pythium alternate among the different growth seasons with potentially different ecological requirements during coinfection with CGMMV. The aim of the current study was to investigate the parameters involved in disease dynamics under coinfection with each of the two Pythium species and CGMMV, and to elucidate the influence of temperature (mild winter versus summer) on each of the two Pythium species with and without viral infection.

\section{Materials and Methods}

Data collection and pathogen isolates. Pythium isolates were collected between January 2014 and December 2015 from collapsed cucumber plants (Supplementary Table S1). These plants were also confirmed to be infected by CGMMV through enzyme-linked immunosorbent assay (ELISA) (Clark and Adams 1977) analysis for the presence of CGMMV coat protein as described by Shargil et al. (2016). Substrate hydrolysis time was $30 \mathrm{~min}$. Optical density (OD) of samples was recorded at $405 \mathrm{~nm}$ by an ELISA reader (Anthos, Salzburg, Austria). In order to ensure that each collected plant was not infected by a mixture of two or more Pythium species, each isolate included combined hyphae of three different segments from root and crown root of each individual plant. DNA from 39 of these Pythium isolates was extracted with the commercial kit MaserPure yeast DNA (Epicenter, Madison, WI) as further described by Philosoph et al. (2018). The DNA was amplified by using primers ITS1 and ITS4 (White et al. 1990). Sequences were compared with the NCBI database, and representative isolates were deposited in GenBank under accession numbers MF116303 and MF118618. The 39 isolates were assigned into one of the four main growing seasons that are commonly practiced in the central Hefer Valley (Ahituv, geographical coordinates: 32.389988, 34.990965).

Temperature responses of $P$. spinosum and $P$. aphanidermatum isolates. In vitro tests were performed to evaluate temperature responses of $P$. spinosum and $P$. aphanidermatum isolates. Among the collection of 39 sequenced isolates, six isolates of $P$. spinosum and six isolates of $P$. aphanidermatum were randomly chosen for the mycelial growth experiments. Agar disks ( $8 \mathrm{~mm}$ diameter) from the margins of 48-h-old colonies were placed in the center of 90-mm agar plates containing potato dextrose agar (PDA) (Difco Laboratories). The plates were maintained at temperatures of 10,15, $20,25,30$, or $35 \pm 1{ }^{\circ} \mathrm{C}$ in incubators (Sanyo, MIR-154) under a 12-h light/dark regime. After $24 \mathrm{~h}$, colony size was measured in two perpendicular directions and colony area was calculated as an ellipse
$[\Pi \times(\mathrm{R} 1 \times \mathrm{R} 2)]$. There were three replicates (petri dishes) per treatment (Pythium isolate $\times$ temperature) and the experiment was repeated once. Gaussian 3-parameter regressions $[\mathrm{f}=\mathrm{a} \times \exp (-0.5\{(\mathrm{x}-\mathrm{x} 0) /$ b $\}^{2}$ )] were computed for each treatment (Bunce 2008; Luo et al. 2001). Optimal temperatures were estimated after calculating the first derivatives of the regression equations using SigmaPlot 12 (Systat Software, San Jose, CA). The differences between the optimal temperatures of $P$. spinosum and $P$. aphanidermatum were compared with a $t$ test $(\alpha=0.05)$.

Pathogen growth and inoculation. $P$. spinosum isolate PS-04$\mathrm{OB}$ and $P$. aphanidermatum isolate PA-03-MA6 were cultured independently on potato dextrose agar (PDA; Difco) and incubated at $25^{\circ} \mathrm{C}$ for 2 days. From each isolate, 10 populated agar disks $(10 \mathrm{~mm})$ were excised from the 48-h-old colony edge and placed in a 500-ml Erlenmeyer flask containing $80 \mathrm{~g}$ of autoclaved pearl millet. The culture was incubated for 5 days at $25^{\circ} \mathrm{C}$. Pythium-colonized millet seeds were homogenized in a Waring blender (Moulinex, France) for $30 \mathrm{~s}$ and adjusted to $0.25 \%$ (wt/wt) in potting mixture (70:30 peat:tuff ratio, Even-Ary, Israel). The control treatment consisted of a mix of $0.25 \%$ noncolonized sterilized millet seeds. CGMMV inoculation was conducted as previously described (Reingold et al. 2015). Briefly, each cucumber plant was mechanically inoculated by gently rubbing the cotyledons with extract from CGMMV-inoculated cucumber plants (Ah isolate, GenBank accession number KF155232). The extract was homogenized in phosphate buffer $(0.01 \mathrm{M}, \mathrm{pH}$ 7) containing Carborundum dust (silicon carbide). The infection buffer was washed off from the cotyledons 5 min postinoculation. Plants with Pythium alone and the noninoculated control were similarly treated with virus-free buffer and Carborundum.

Plant growth conditions. Commercially disinfected cucumber seeds (cv. Kefir Zeraim Gedera, Israel) were sown in a nursery tray containing potting mixture in a pest- and disease-free greenhouse at $23 \pm 1{ }^{\circ} \mathrm{C}$. The germinated seedlings were kept under a 12 -h photoperiod, and were fertilized and irrigated with drippers twice a day ( 0.1 liter per irrigation) with 5:3:8 NPK fertilizer (irrigation water planned to contain total N, P, and K concentrations of 120,30 , and $150 \mathrm{mg} / \mathrm{liter}$, respectively; EC $2.2 \mathrm{dS} / \mathrm{m}$ ), allowing for 25 to $50 \%$ drainage.

Aggressiveness of $\boldsymbol{P}$. spinosum and $\boldsymbol{P}$. aphanidermatum isolates at different temperatures in controlled-environment experiments. Plant seedlings were grown before inoculation as described above until 6 days after sowing. Four cucumber seedlings of uniform growth were transplanted into each pot (3 liter, 16-cm-diameter) containing potting mixture (peat:tuff 7:3 vol/vol, Shaham, Givat Ada, Israel). Treatments (at least 16 pots per treatment) were conducted in three different controlled-environment growth chambers (at least 192 plants in each chamber) at 18,25 , and $32^{\circ} \mathrm{C}$. A Hobo Data logger U12-012 (Onset, Bourne, MA) was used to document the soil and air temperatures in each chamber. The soil temperatures at $5 \mathrm{~cm}$ depth were $18.3 \pm 0.10,24.4 \pm 0.07$, and $32.1 \pm 0.07^{\circ} \mathrm{C}$, respectively. In each chamber, three treatments were performed (for a minimum of 64 plants per treatment): (i) pathogen-free, (ii) inoculation with $P$. spinosum, (iii) inoculation with $P$. aphanidermatum. Damping-off incidence in the plants during the first 8 days, until mortality ceased, was used to draw disease-progress curves and calculate the area under the mortality progress curve (AUMPC, in $\% \times$ days), representing the intensity of the entire epidemic in each treatment. AUMPC was determined as previously described (Jaiswal et al. 2014). The experiments were repeated twice.

Combined infection of CGMMV and Pythium spp. at different temperatures under controlled conditions experiments. These experiments were initiated with the surviving 14-day-old plants from the previous stage (i.e., the damping-off experiment) to mimic the scenario in commercial cucumber greenhouses in which Pythiuminfested plants survive the first wave of seedling damping-off but still host Pythium in their tissues. Therefore, after the initial 8 days postinoculation in the previous set of experiments, 96 surviving plants were selected from each of the growth chambers set the three temperatures $\left(18,25\right.$, and $\left.32^{\circ} \mathrm{C}\right)$, which included 32 plants from each of the 
following treatments: (i) pathogen-free, (ii) inoculation with $P$. spinosum, (iii) inoculation with $P$. aphanidermatum. For each of the three temperatures, the plants were used to create four new blocks, each containing 16 plants from each of the following treatments: (i) pathogen-free, (ii) inoculation with $P$. spinosum, (iii) inoculation with $P$. aphanidermatum, (iv) inoculation with CGMMV, (v) inoculation with both CGMMV and $P$. spinosum, and (vi) inoculation with both CGMMV and $P$. aphanidermatum (in total 96 plants in each chamber). During the experiment, the mortality rate was documented along with CGMMV symptom development. The experiment was repeated twice. As lengths of the two repeated experiments differed (23 and 40 days, respectively), we normalized the epidemic parameters using the Relative AUMPC (Jaiswal et al. 2014) for mortality and the relative area under the disease progress curve (RAUDPC) for viral symptoms. The documented mortality rate was also used to calculate the synergistic effect of CGMMV and Pythium spp. using the Abbott formula (Kosman and Cohen 1996; Levy et al. 1986) as described by Philosoph et al. (2018). At the end of the experiments, leaves from each treatment group were collected for CGMMV detection $(\sim 200 \mathrm{mg})$. The leaves were ground in a general extraction buffer (Bioreba, Switzerland) and the presence of CGMMV was detected by ELISA (Clark and Adams 1977) using commercial CGMMV antibodies (Agdia, U.S.A.) and CGMMV-positive and negative references. Substrate hydrolysis time was $20-40 \mathrm{~min}$. Plates were recorded at $405 \mathrm{~nm}$ using an ELISA reader (Multiskan Fc, Thermo Scientific). Positive ELISA results were calculated based on a minimum ratio of three times of the Negative Reference $(3 \mathrm{xNR})$ as described by Shargil et al. (2016). In addition, the roots from all plants were examined for the presence of Pythium spp. using selective corn meal agar as described by Philosoph et al. (2018).

Statistical analysis. The controlled-environment chamber experiments were conducted twice. In each experimental set, the results of the experimental repeats were firstly pooled and analyzed jointly with 'experiment' as an additional block factor. As no significant differences were observed between the two experimental repeats, and there were furthermore no significant effects of the experiment factor and the other main interactions $(P>0.391)$ (Supplementary Tables S2 and S3), the data of repeated experiments were combined into one dataset for further analysis.

Data were analyzed by two-way analysis of variance (ANOVA) for Pythium aggressiveness, with Pythium species and temperature as main factors and their interactions. For the effect of combined infection at different temperatures, a three-way ANOVA model was applied with Pythium species, temperature, and CGMMV infection as main factors and their interactions using JMP 14 software (SAS Institute, Cary, NC). To enable ANOVA, percentage values were normalized by arcsine square-root transformation. Multiple comparisons of the means were conducted by using Tukey-Kramer honestly significant difference (HSD) test $(\alpha=0.05)$. To calculate the impact of the combined infection at different temperatures based on the percentage of viral symptomatic plants in each block (CGMMV, CGMMV $+P$. spinosum, CGMMV $+P$. aphanidermatum $)$, within each temperature, a $\chi^{2}$ test $(\alpha=0.05)$ was used to compare the proportion of CGMMV, CGMMV $+P$. spinosum, and CGMMV $+P$. aphanidermatum infected plants.

\section{Results}

Data collection and pathogen isolates. Two Pythium species, $P$. spinosum and $P$. aphanidermatum ( $>99.2 \%$ identity to NCBI accessions KU208387 and AY598622, respectively), were detected among the 39 sequenced isolates. All of the plants were infected by a single species. $P$. spinosum was detected between November and May-Israeli winter until late spring (Fig. 1A). P. aphanidermatum was detected between April and October (Fig. 1A) - late spring, summer, and autumn. The corresponding average temperatures are presented in Figure 1B.

Growth responses of $\boldsymbol{P}$. spinosum and $\boldsymbol{P}$. aphanidermatum under different temperatures. Differences between the in vitro growth responses of the $P$. spinosum and $P$. aphanidermatum isolates at different temperature were highly significant $(P<0.001)$. For the six tested $P$. spinosum isolates, the optimal temperature range was $25.8 \pm 0.35^{\circ} \mathrm{C}$ (Fig. 2A) and for the six P. aphanidermatum isolates, $32.8 \pm 0.37^{\circ} \mathrm{C}$ (Fig. 2B).

Aggressiveness of $P$. spinosum and $P$. aphanidermatum isolates at different temperatures under controlled environment. The two main factors 'temperature' and 'Pythium spp.' and their interaction were significant $(P<0.045)$. For $P$. spinosum, the final mortality incidence (FMI) at $18^{\circ} \mathrm{C}$ was significantly higher than at $25^{\circ} \mathrm{C}$ and $32^{\circ} \mathrm{C}$ (Fig. 3); similarly the AUMPC values related to $P$. spinosum were significantly higher at $18^{\circ} \mathrm{C}$ compared with 25 and $32^{\circ} \mathrm{C}$ (Supplementary Fig. S1). For P. aphanidermatum, the FMI at $18^{\circ} \mathrm{C}$ was significantly lower than those at $25^{\circ} \mathrm{C}$ and $32^{\circ} \mathrm{C}$ (Fig. 3), with a similar pattern for the AUMPC values. While comparing the aggressiveness measures between the two Pythium spp. within each temperature, $P$. spinosum was more aggressive than $P$. aphanidermatum at $18^{\circ} \mathrm{C}$ while $P$. aphanidermatum was more aggressive than $P$. spinosum at $25^{\circ} \mathrm{C}$ and $32^{\circ} \mathrm{C}$ (Fig. 3).

The effect of combined infection of CGMMV and Pythium spp. on disease severity at different temperatures under controlled conditions. In these experiments, which were conducted on the 14-day-old surviving seedlings from the previous experiment, the three-way interaction of 'Pythium spp.' $\times$ 'temperature' $\times$ 'CGMMV' was significant $(P<0.022)$. For the plants infected with $P$. spinosum without CGMMV infection, mortality of seedlings was very low $(\mathrm{FMI}=3.12 \%)$ and was only detected at $18^{\circ} \mathrm{C}$ and $32^{\circ} \mathrm{C}$ (Fig. 4A). However, during the combined infection with CGMMV, significantly higher mortality incidences were detected at each
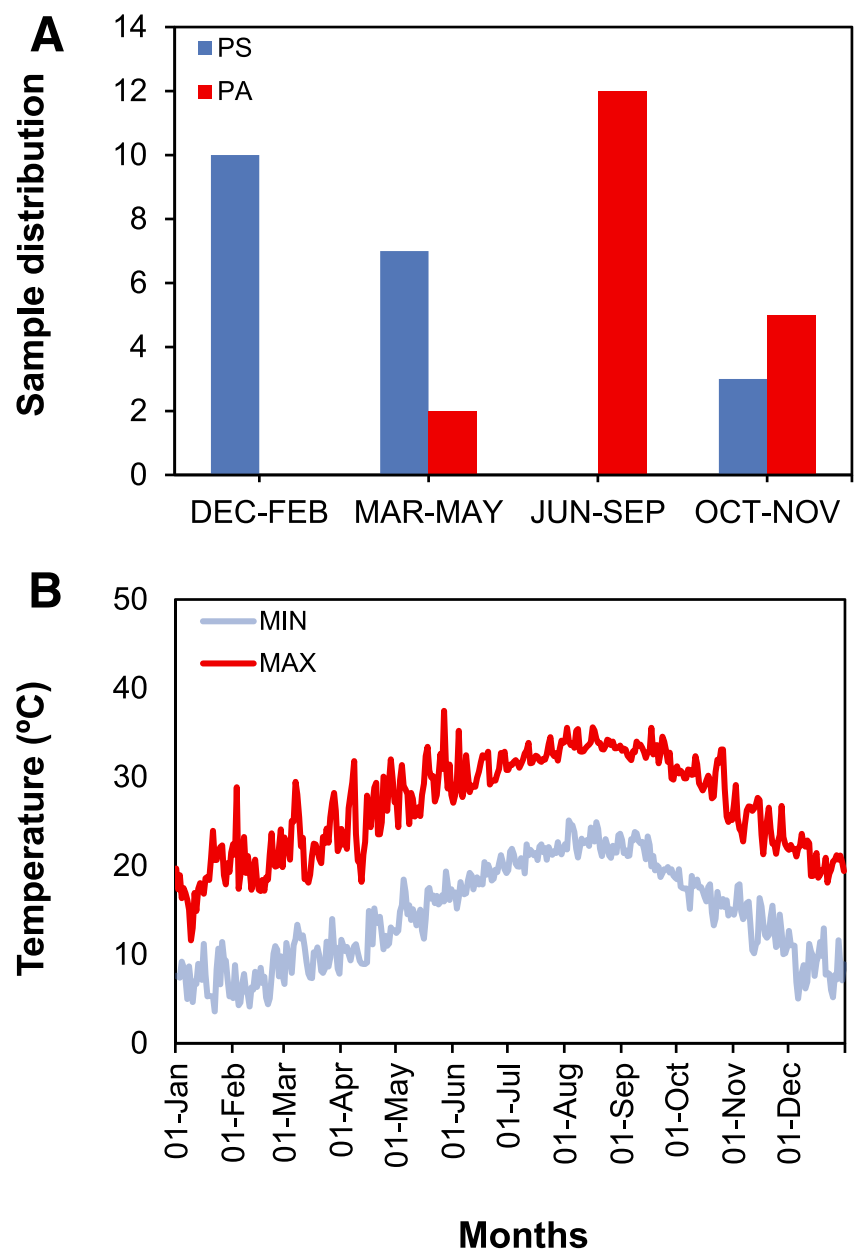

Fig. 1. (A) Distribution of 19 Pythium aphanidermatum (PA) and 20 P. spinosum (PS) isolates during the four main growing seasons of cucumber in central Israel. (B) Average minimum and maximum temperatures of "Maor meteorological station" (Ahituv area) during the 2014-2015 growing seasons measured $0.5 \mathrm{~m}$ above the ground (http://www.meteo.co.il). 
temperature $(P<0.001$, Fig. 4A), resulting in a high synergistic effect (Table 1). The FMI of the combined infection were $56.25 \%$ at $18{ }^{\circ} \mathrm{C}$, $25 \%$ at $25^{\circ} \mathrm{C}$, and an unexpected mortality of $43.75 \%$ at $32^{\circ} \mathrm{C}$ and with no significant differences between the temperatures (Fig. 4A). Similar pattern was detected for the RAUMPC values of the three temperatures $(19.6 \pm 6.28,8.1 \pm 1.80$, and $19.4 \pm 7.42$ for 18,25 , and $32{ }^{\circ} \mathrm{C}$, respectively Supplementary Fig. 2A). The mortality of seedlings infected with $P$. aphanidermatum alone only occurred at $32^{\circ} \mathrm{C}$, with a relatively low mortality rate of $12.5 \%$ (Fig. 4B). The FMI of the combined infection was temperature-dependent and was significantly lower at $18^{\circ} \mathrm{C}(6.25 \%)$. Final mortality incidence values were also significantly different between $25^{\circ} \mathrm{C}(31.2 \%)$ and $32^{\circ} \mathrm{C}(62.5 \%)$ (Fig. 4B). These results of the combined infection were also reflected with strong synergistic effect at $25^{\circ} \mathrm{C}$ and $32^{\circ} \mathrm{C}$ (Table 1). Similar pattern was detected for the RAUMPC values of the three temperatures $(1.1 \pm 0.92,13.3 \pm 2.77$, and $26.4 \pm 5.68$ for 18,25 , and $32^{\circ} \mathrm{C}$, respectively), but with no significant difference between $25^{\circ} \mathrm{C}$ and $32^{\circ} \mathrm{C}$. No mortality was observed for the noninoculated control or for CGMMV infection alone.

Effect of temperature and combined infection with CGMMV and Pythium spp. on CGMMV symptom appearance. Temperatures affected the development of CGMMV symptoms (Table 2 and Supplementary Fig. S3). At 32 and $25^{\circ} \mathrm{C}$, first symptoms appeared 6 days and 9 days post-CGMMV inoculation, respectively. A longer delay was observed at $18^{\circ} \mathrm{C}$, where early symptoms were visualized on day 18 post-CGMMV inoculation. The influence of temperature (based on the RAUDPC values) was significantly higher as the temperature increased $(P \leq 0.005)$. However, within each temperature, no significant influence of the combined infection was

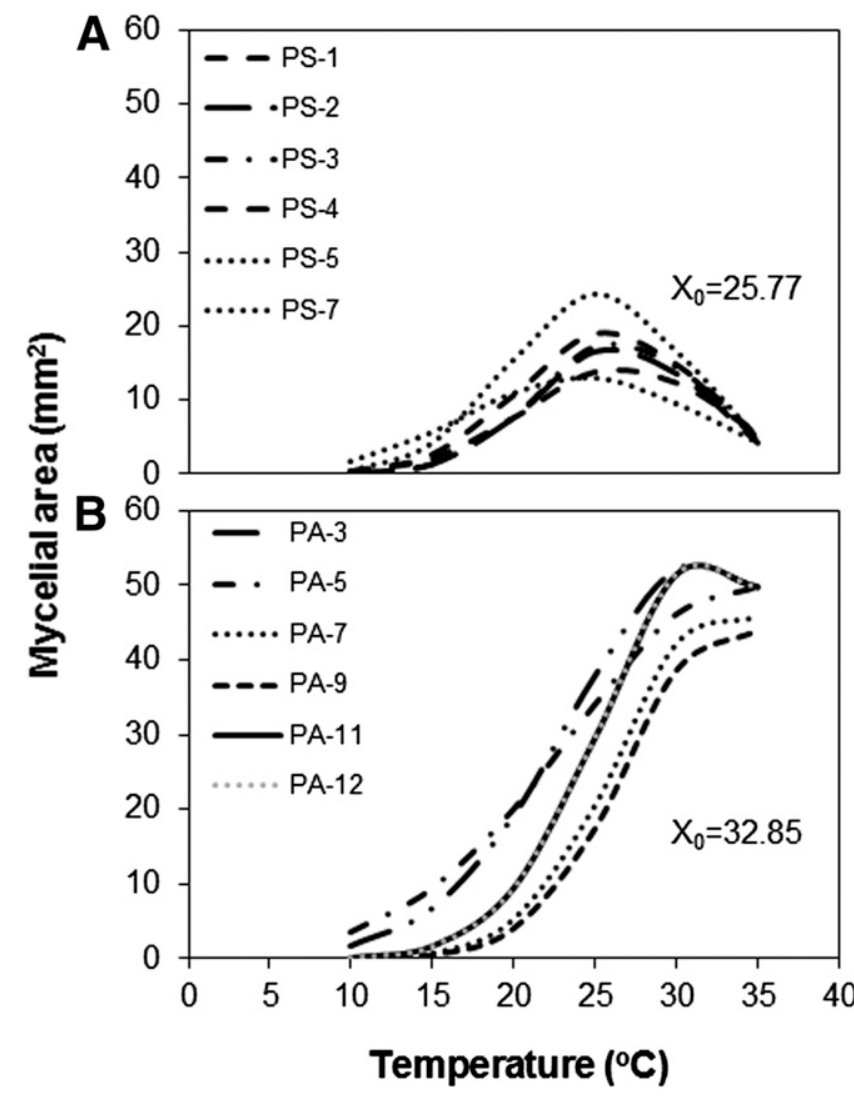

Fig. 2. Mycelial growth area of (A) six Pythium spinosum isolates (PS) and (B) six $P$. aphanidermatum isolates (PA) grown in PDA plates and maintained at $10,15,20,25$, 30 , or $35 \pm 1^{\circ} \mathrm{C}$. Colony area was calculated after $24 \mathrm{~h}$. Gaussian 3-parameter regressions $\left[f=a \times \exp \left(-0.5\{(x-x 0) / b\}^{2}\right)\right]$ were calculated for each treatment. Optimal temperatures were estimated after calculating the first derivatives of the regression. There were three replicates (petri dishes) per treatment (Pythium isolate $x$ temperature) and the experiment was repeated once. Values are the average of the experiments. detected for the RAUDPC of the viral symptoms with either of the Pythium spp. (Table 2). The ELISA OD reads for all the treatments with CGMMV ranged between 0.10 and 0.18 (compared with 0.011-0.013 for the NR and 0.016-0.024 for samples infected with Pythium spp. alone or noninoculated controls) demonstrating no differences regardless of temperature and the combined infection (Table 2). Values for all the treatments without the CGMMV infection (i.e., Pythium alone and noninoculated control) were below the value of 0.05 as expected from noninfected treatments).

\section{Discussion}

In the last 50 years, the importance of coinfection and pathogen complexes have been demonstrated in several pathosystems (Lamichhane and Venturi 2015). Most descriptions have focused on complexes of pathogens from the same kingdom [ascochyta blight in pea (Le May et al. 2009); soybean wilt (Barros et al. 2014); mosaic disease in cucurbits (Salvaudon et al. 2013)], while several studies have indicated that viral-fungal/oomycete interactions also play an important role in plant diseases (Ito et al. 2017; Koike and Yang 1971; Zitter 1995). Nonetheless, there are very few in-depth studies on viral-fungi or viral-oomycetes, with most of these focusing on a description of the phenomenon per se, such as Pythium ultimum and cucumber mosaic virus (CMV) in cucumber (Nitzany 1966), Septoria apiicola and celery mosaic virus (CeMV) in celery (Ataga et al. 1999), and Peronosclerospora sorghi and maize streak virus (MSV) in maize (Damsteegt et al. 1993). Important questions regarding the influence of environmental conditions on these complexed pathosystems have been studied to a lesser extent.

Here, we report on a broader aspect of the pathogen coinfection. Combined infection may result in not only a higher, synergistic effect at pathogens' optimal temperatures, but also unexpected new and severe symptoms occurring under suboptimal conditions for the pathogens that exhibit very minor damage when present as single infections.

Monoculture practice of cucumber cultivation in Israel enabled detection of the temporal dynamics of two different Pythium spp. P. aphanidermatum was dominant in the warmer summer months, whereas $P$. spinosum dominated during the comparably colder winter

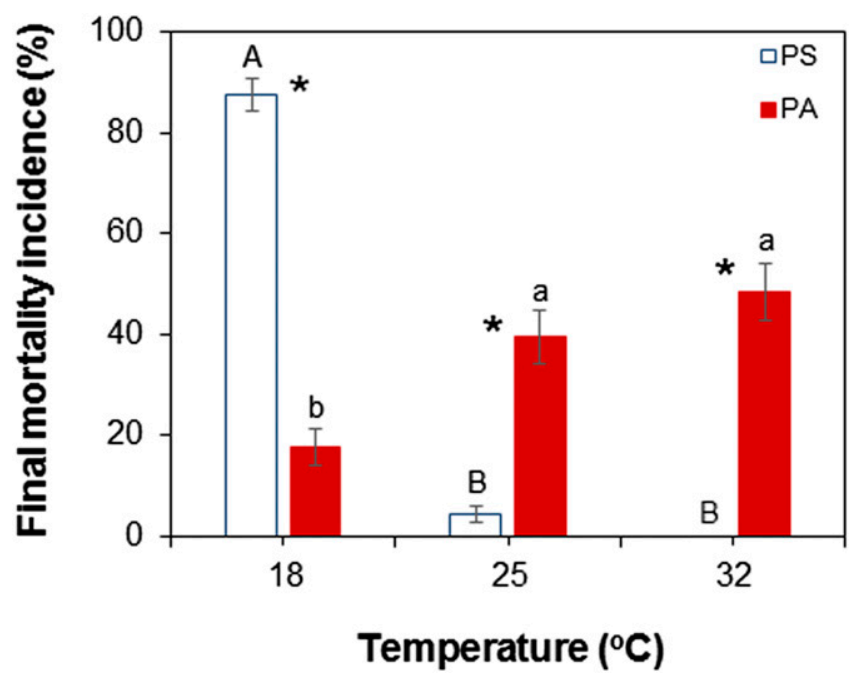

Fig. 3. Final mortality incidence (FMI) of cucumber plants infected with Pythium alone in three controlled-environment chambers set at 18,25 , and $32^{\circ} \mathrm{C}$, upon inoculation with Pythium spinosum (PS) or P. aphanidermatum (PA). Six-day-old seedlings were inoculated with one of the Pythium spp. Final mortality incidence was calculated until day 8 . No mortality was observed for the noninoculated control. Columns labeled by a common capital letter and small letter are not significantly different at $\alpha \leq 0.05$ according to Tukey-Kramer HSD test within PS and PA treatments, respectively. Asterisk denotes a significant difference at $\alpha \leq 0.05$ between the two Pythium spp. (PS versus PA) at the same temperature. Bars = standard error. The values represent the average of two experiments; each experiment contains at least 64 plants per treatment. 
months. In addition, during the spring and autumn seasons, a mixed population of the two species was present. These results concur with previous reports on these pathogens from around the world (Al-Sadi et al. 2007; Gherbawy and Abdelzaher 2002; Stirling et al. 2004) and are in line with the in vivo and in vitro experiments conducted in our study. CGMMV epidemics persist during all seasons at the background of commercial cucumber greenhouses and under diverse environmental conditions (Dombrovsky et al. 2017), potentially providing an additional and essential pathogen for coinfection with either of the Pythium spp.

Each of the two tested Pythium spp. is known mostly as a causal agent of early damping-off exhibiting only minor symptoms in mature cucumber plants ( $>14$ days after planting), while CGMMV infection causes mottle and mosaic symptoms. The fact that their combination resulted in the sudden occurrence of late wilting demonstrates that the late wilting disease of cucumber is caused by the coinfection of an oomycete and the virus. Late wilting disease on plants older than 14 days, involving CGMMV and $P$. aphanidermatum, demonstrated a similar pattern to the damping-off disease caused by $P$. aphanidermatum alone on 6-day-old seedlings with regards to the optimal temperature required for causing both diseases. One of the unexpected outcomes of this research was the fact that
$P$. spinosum, which caused almost no damage at high temperatures during the early damping-off epidemics on 6-day-old seedlings, became highly aggressive under the suboptimal condition of $32^{\circ} \mathrm{C}$ when CGMMV was introduced 14 days postplanting.

Wilting phenomena resulting from viral diseases associated with root necrosis have been reported in several cases (Duggal and Lakhanpal 1981; García-Jiménez et al. 2000; Pearson et al. 1993; Soler-Aleixandre et al. 2005), but their potential connection with minor soilborne pathogens, and their interaction with environmental conditions, have been underestimated. Gergerich and Dolja (2006) pointed out that under different environmental conditions, a plant's response to viral infection may range from symptomless to severe disease and plant death. It would be interesting to challenge known and future extensive collapse events related to viruses with the broader aspect of virus-minor pathogen systems while further considering environmental aspects in such pathosystems.

Fluctuating weather conditions, including sudden heat waves, are common in many parts of the world and their frequency rises (Cramer et al. 2018; Rosenzweig et al. 2001). These conditions are also quite common in the Middle East and the Mediterranean region, which are characterized by hot summers, cool winters, and relatively mild weather conditions during the spring and autumn that are commonly
$A$

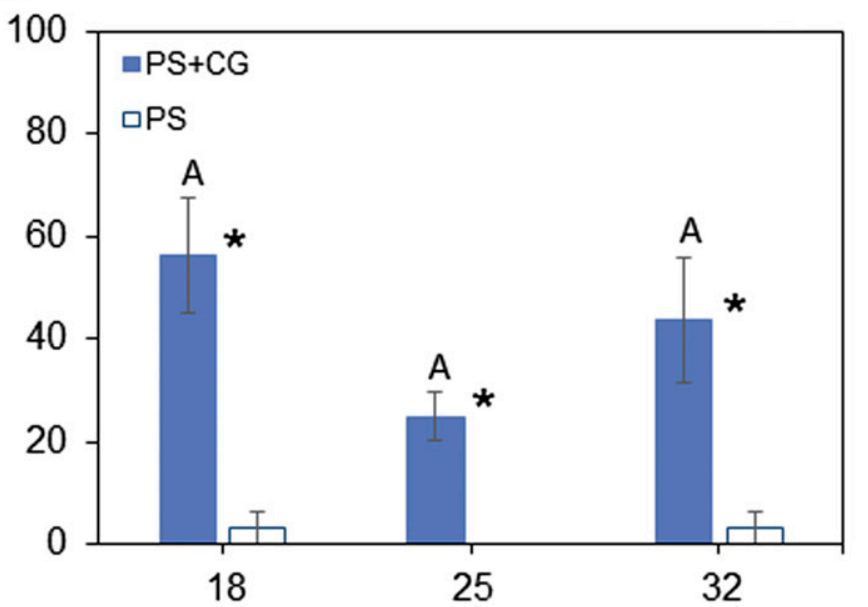

18

25

32
B



Temperature $\left({ }^{\circ} \mathrm{C}\right)$

Fig. 4. Final mortality incidence (FMI) of cucumber plants in the combined infection experiment with cucumber green mottle mosaic virus (CGMMV) and each of the Pythium sp. Experiments were set in three controlled-environment chambers at 18,25 , and $32^{\circ} \mathrm{C}$, upon inoculation with (A) Pythium spinosum and CGMMV (PS+CG) or $P$. spinosum alone (PS), and cucumber plants upon inoculation with (B) $P$. aphanidermatum and CGMMV (PA+CG) or $P$. aphanidermatum alone (PA). Seedlings were inoculated with CGMMV 8 days after inoculation with one of the Pythium sp. Final mortality incidence was calculated from 10 days after Pythium spp. inoculation (i.e., 2 days after CGMMV inoculation) until the end of the experiment. No mortality was observed for the noninoculated control or for seedlings inoculated with CGMMV alone. Columns labeled by a common capital letter are not significantly different at $\alpha \leq 0.05$, according to Tukey-Kramer HSD test, between the different temperatures in (A) PS+CG or (B) PA+CG treatments. Within each temperature, asterisk denotes a significant difference at $\alpha \leq 0.05$ at (A) PS+CG versus PS or (B) PA+CG versus PA. Bars $=$ standard error. The values represent the average of two experiments; each experiment contains 16 plants per treatment.

Table 1. Analysis of synergy factor (SF) based on relative area under the mortality progress curve (RAUMPC) values for combined infection with cucumber green mottle mosaic virus (CG) and P. spinosum (PS) or P. aphanidermatum (PA)

\begin{tabular}{lcccccc}
\hline \multicolumn{7}{c}{ RAUMPC $(\% \times$ days $)$} \\
\hline Pythium spp. & Temperature (Celsius) & CG + Pythium & Pythium & Control & CG & SF \\
\hline PS & 18 & $19.59 \pm 6.28$ & $2.73 \pm 0.02$ & 0 & 0 & $7.17 \pm 2.29$ \\
PS & 25 & $8.12 \pm 1.80$ & 0 & 0 & 0 & NCSF \\
PS & 32 & $19.41 \pm 7.42$ & $1.63 \pm 0.01$ & 0 & 0 & $11.9 \pm 4.55$ \\
PA & 18 & $1.07 \pm 0.92$ & 0 & 0 & 0 & NS $^{\mathrm{b}}$ \\
PA & 25 & $13.32 \pm 2.77$ & 0 & 0 & 0 & NCSF \\
PA & 32 & $26.38 \pm 5.68$ & $4.79 \pm 0.03$ & 0 & 0 & $5.50 \pm 1.18$ \\
\hline
\end{tabular}

${ }^{a}$ NCSF, noncalculated synergistic factor, representing high synergistic values that cannot be calculated with the Abbott formula since Pythium RAUMPC values were 0 .

${ }^{\mathrm{b}} \mathrm{NS}={ }^{\mathrm{C}} \mathrm{CG}+$ Pythium' treatment was not significantly different from 0 , therefore the SF value is also not significant. 
interrupted by high-temperature events (above $30^{\circ} \mathrm{C}$ ) (Fig. 1B) (Brunetti et al. 2004). These events might explain the occurrence, in specific greenhouses during the spring and autumn, of extended plant collapse, where $P$. spinosum and CGMMV are detected as causal agents, but not $P$. aphanidermatum.

Our findings also raise new questions about the mechanisms that underlie this synergistic damage and new symptoms. One of the main questions is the role of the virus itself in this complex pathosystem. Based on a previous report (Philosoph et al. 2018) and our current study, we concluded that late plant collapse of cucumber is a complex disease that is not caused by CGMMV alone. In addition, typical CGMMV symptoms (leaf mosaic and mottling) develop earlier at higher temperatures and vice versa for the colder temperatures. Interestingly, the fact that coinfection of CGMMV with $P$. spinosum leads to extended cucumber plant collapse under the latter's suboptimal condition of $32^{\circ} \mathrm{C}$, whereas coinfection of CGMMV and P. aphanidermatum barely causes any plant collapse under its suboptimal condition at $18^{\circ} \mathrm{C}$, suggests that CGMMV infection contributes an indirect weakening effect on the plant's defense system. Increased expression of viral particles that partially clog the plant xylem and phloem vessels (French and Elder 1999; Moreno et al. 2004; Reingold et al. 2016) may also contribute to the plants' susceptibility to collapse. Indeed, no statistical differences were observed in the appearance of the virus symptoms with or without the Pythium spp. and no significant differences were detected in the leaf tissues by ELISA. Nevertheless, there is a possibility that the viral and oomycetes interaction under the mixed infection (and the different temperatures) promotes the accumulation of viral particles or oomycetes mycelium in other plant tissues such as the roots and the lower parts of the transport system. This aspect needs to be further tested by a substantial quantitative and univocal methods such as Quantitative RT-PCR for both Pythium and CGMMV.

It is possible that the complex interaction with abiotic stress (e.g., heat) is an additional factor in the plant's response to viral infection, resulting in increased or decreased tolerance to pathogens (Patel and Franklin 2009). It has been found that infection with several independent viruses at high temperatures results in a reduction in plant hormone levels, such as salicylic acid (Malamy 1992), weakening the plant's defense mechanism and inhibiting its ability to cope with

Table 2. Calculated impact of relative area under the disease progress curve (RAUDPC) based on the percentage of plants with foliar symptoms of cucumber green mottle mosaic virus (CGMMV). Treatments included infection with CGMMV alone (CG); or with combined infection of CGMMV with $P$. spinosum $(\mathrm{CG}+\mathrm{PS})$ or $P$. aphanidermatum $(\mathrm{CG}+\mathrm{PA})$ at different temperatures.

\begin{tabular}{lcc}
\hline Treatments & RAUDPC average & $\begin{array}{c}\text { ELISA OD } \\
\text { average and range }\end{array}$ \\
\hline $\mathrm{CG}-18^{\circ} \mathrm{C}$ & 19.78 & $0.09(0.088-0.102)$ \\
$\mathrm{CG}+\mathrm{PS}-18^{\circ} \mathrm{C}$ & $23.03 \mathrm{~ns}{ }^{\mathrm{d}}$ & $0.14(0.125-0.155)$ \\
$\mathrm{CG}+\mathrm{PA}-18^{\circ} \mathrm{C}$ & $19.78 \mathrm{~ns}$ & $0.11(0.089-0.146)$ \\
Average & $20.9 \pm 1.08$ & $0.12 \pm 0.013$ \\
$\mathrm{CG}-25^{\circ} \mathrm{C}$ & 48.96 & $0.12(0.115-0.124)$ \\
$\mathrm{CG}+\mathrm{PS}-25^{\circ} \mathrm{C}$ & $49.58 \mathrm{~ns}$ & $0.14(0.147-0.147)$ \\
$\mathrm{CG}+\mathrm{PA}-25^{\circ} \mathrm{C}$ & $47.33 \mathrm{~ns}$ & $0.16(0.136-0.180)$ \\
Average & $48.6 \pm 0.67$ & $0.14 \pm 0.011$ \\
$\mathrm{CG}-32^{\circ} \mathrm{C}$ & 63.29 & $0.10(0.099-0.106)$ \\
$\mathrm{CG}+\mathrm{PS}-32^{\circ} \mathrm{C}$ & $62.93 \mathrm{~ns}$ & $0.13(0.114-0.147)$ \\
$\mathrm{CG}+\mathrm{PA}-32^{\circ} \mathrm{C}$ & $56.06 \mathrm{~ns}$ & $0.13(0.107-0.177)$ \\
Average & $60.8 \pm 2.35$ & $0.12 \pm 0.009$ \\
\hline
\end{tabular}

a The data include the average of two experiments. In each experiment, each treatment included 16 plants.

${ }^{\mathrm{b}} \mathrm{OD}=$ Optical density.

c The ELISA results were considered positive for a minimum ratio of three times that of the Negative Reference (3xNR); the NR ranged in our experiments between 0.011 and 0.013 . The ELISA values for our noninoculated control plants or those with Pythium spp. alone ranged between 0.016 and 0.024 .

${ }^{\mathrm{d}} \mathrm{ns}=$ nonsignificant difference; Within each temperature, $\chi^{2}$ test $(\alpha=0.05)$ was used to compare the proportions of CG, CG+PS, and CG+PA, infected plants. $(\alpha=0.05)$. the viral pathogen (Malamy 1992; Yalpani et al. 1991). In addition, the different hormonal pathways that are influenced by these stresses might negatively interact with the expression of other important defense systems and weaken the plant's reaction during the combined infection (Thaler et al. 2012). These hypotheses need to be further investigated using a high-throughput transcriptomic sequencing platform to reveal the complexity of the plant's defense mechanisms against plant pathogens during single infections and coinfections, e.g., with oomycetes or fungi, under fluctuating environmental conditions.

\section{Acknowledgments}

We thank, Neta Mor, Menachem Borenstein, Oded Lachman, and Sigal Peretz for their valuable assistance in the laboratory and field experiments.

\section{Literature Cited}

Abdullah, A. S., Moffat, C. S., Lopez-Ruiz, F. J., Gibberd, M. R., Hamblin, J., and Zerihun, A. 2017. Host-multi-pathogen warfare: Pathogen interactions in coinfected plants. Front. Plant Sci. 8:1-12.

Adams, M. J., Antoniw, J. F., and Kreuze, J. 2009. Virgaviridae: A new family of rod-shaped plant viruses. Arch. Virol. 154:1967-1972.

Ainsworth, G. C. 1935. Mosaic disease of cucumber. Ann. Appl. Biol. 22:55-67.

Al-Sadi, A. M., Al-Masoudi, R. S., Al-Habsi, N., Al-Said, F. A., Al-Rawahy, S. A., Ahmed, M., and Deadman, M. L. 2010. Effect of salinity on pythium dampingoff of cucumber and on the tolerance of Pythium aphanidermatum. Plant Pathol. 59:112-120.

Al-Sadi, A. M., Drenth, A., Deadman, M. L., Al-Said, F. A., Khan, I., and Aitken, E. A. B. 2008. Potential sources of Pythium inoculum into greenhouse soils with no previous history of cultivation. J. Phytopathol. 156:502-505.

Al-Sadi, A. M., Drenth, A., Deadman, M. L., De Cock, A., and Aitken, E. A. B 2007. Molecular characterization and pathogenicity of Pythium species associated with damping-off in greenhouse cucumber (Cucumis sativus) in Oman. Plant Pathol. 56:140-149.

Antignus, Y., Pearlsman, M., Ben-Yoseph, R., and Cohen, S. 1990. Occurrence of a variant of Cucumber green mottle mosaic virus in Israel. Phytoparasitica 18: $50-56$.

Antignus, Y., Wang, Y., Pearlsman, M., Lachman, O., Lavi, N., and Gal-On, A. 2001. Biological and molecular characterization of a new cucurbit-infecting tobamovirus. Phytopathology 91:565-571.

Ataga, A. E., Epton, H. A. S., and Frost, R. R. 1999. Interaction of virus-infected celery and Septoria apiicola. Plant Pathol. 48:620-626.

Ayo-John, E. I., Olorunmaiye, P. M., Odedara, O. O., Olusayo, B. D., Abiola, K. O., and Oladokun, J. O. 2014. Assessment of field-grown cucurbit crops and weeds within farms in south-west Nigeria for viral diseases. Not. Sci. Biol. 6:321-325.

Barros, G. G., Zanon, M. S. A., Chiotta, M. L., Reynoso, M. M., Scandiani, M. M., and Chulze, S. N. 2014. Pathogenicity of phylogenetic species in the Fusarium graminearum complex on soybean seedlings in Argentina. Eur. J. Plant Pathol. 138:215-222.

Ben-Yephet, Y., and Nelson, E. B. 1999. Differential suppression of damping-off caused by Pythium aphanidermatum, $P$. irregulare, and $P$. myriotylum in composts at different temperatures. Plant Dis. 83:356-360.

Brunetti, M., Buffoni, L., Mangianti, F., Maugeri, M., and Nanni, T. 2004. Temperature, precipitation and extreme events during the last century in Italy. Global Planet. Change 40:141-149.

Bunce, J. A. 2008. Acclimation of photosynthesis to temperature in Arabidopsis thaliana and Brassica oleracea. Photosynthetica 46:517-524.

Choi, G.-S. 2001. Occurrence of two tobamovirus diseases in cucurbits and control measures in Korea. Plant Pathol. J. 17:243-248.

Clark, M. F., and Adams, A. N. 1977. Characteristics of the microplate method of enzyme-linked immunosorbent assay for the detection of plant viruses. J. Gen. Virol. 34:475-483.

Coffua, L. S., Veterano, S. T., Clipman, S. J., Mena-Ali, J. I., and Blair, J. E. 2016 Characterization of Pythium spp. associated with asymptomatic soybean in southeastern Pennsylvania. Plant Dis. 100:1870-1879.

Cramer, W., Guiot, J., Fader, M., Garrabou, J., Gattuso, J. P., Iglesias, A., Lange, M. A., Lionello, P., Llasat, M. C., Paz, S., Peñuelas, J., Snoussi, M., Toreti, A. Tsimplis, M. N., and Xoplaki, E. 2018. Climate change and interconnected risks to sustainable development in the Mediterranean. Nat. Clim. Chang. 8:972-980.

Damsteegt, V. D., Bonde, M. R., and Hewings, A. D. 1993. Interactions between Maize streak virus and downy mildew fungi in susceptible maize cultivars. Plant Dis. 77:390-392.

Dombrovsky, A., Tran-Nguyen, L. T., and Jones, R. A. 2017. Cucumber green mottle mosaic virus: Rapidly increasing global distribution, etiology, epidemiology, and management. Annu. Rev. Phytopathol. 55:1-26.

Duggal, S., and Lakhanpal, T. N. 1981. Histopathology of Capsicum pendulum Willd. Infected with Potato virus X. Acta. Bot. Indica 9:175-180.

French, C. J., and Elder, M. 1999. Virus particles in guttate and xylem of infected cucumber (Cucumis sativus L.). Ann. Appl. Biol. 134:81-87. 
García-Jiménez, J., Armengol, J., Sales, R., Jordá, C., and Bruton, B. D. 2000. Fungal pathogens associated with melon collapse in Spain. EPPO Bull. 30:169-173.

Gergerich, R. C., and Dolja, V. V. 2006. Introduction to Plant Viruses, the Invisible Foe. The Plant Health Instructor, https://doi.org/10.1094/PHI-I-2006-0414-01

Gherbawy, Y. A. M. H., and Abdelzaher, H. M. A. 2002. Using of RAPD-PCR for Separation of Pythium spinosum Sawada into two varieties: var. spinosum and var. sporangiiferum. Cytologia (Tokyo) 67:83-94.

Hendrix, F. F., and Campbell, W. A. 1973. Pythiums as plant pathogens. Annu. Rev. Phytopathol. 11:77-98.

Inoue, T. 1967. Studies on Cucumber green mottle mosaic virus in Japan. Nogaku Kenkyu. 51:175-186.

Ito, M., Meguro-Maoka, A., Maoka, T., Akino, S., and Masuta, C. 2017. Increased susceptibility of potato to Rhizoctonia diseases in Potato leafroll virus-infected plants. J. Gen. Plant Pathol. 83:169-172.

Jaiswal, A. K., Elad, Y., Graber, E. R., and Frenkel, O. 2014. Rhizoctonia solani suppression and plant growth promotion in cucumber as affected by biochar pyrolysis temperature, feedstock and concentration. Soil Biol. Biochem. 69: 110-118.

Koike, H., and Yang, S. 1971. Influence of Sugarcane mosaic virus strain H and Pythium graminicola on growth of sugarcane. Phytopathology 61:1090-1092.

Kosman, E., and Cohen, Y. 1996. Procedures for calculating and differentiating synergism and antagonism in action of fungicide mixtures. Phytopathology 86:1263-1272.

Lamichhane, J. R., and Venturi, V. 2015. Synergisms between microbial pathogens in plant disease complexes: A growing trend. Front. Plant Sci. 6:385.

Le May, C., Potage, G., Andrivon, D., Tivoli, B., and Outreman, Y. 2009. Plant disease complex: Antagonism and synergism between pathogens of the Ascochyta blight complex on pea. J. Phytopathol. 157:715-721.

Lee, K. Y. 1996. Current occurrence and control of CGMMV 'Konjak' disease. Plant Dis Agric. 2:28-39.

Levy, Y., Benderly, M., Cohen, Y., Gisi, U., and Bassand, D. 1986. The joint action of fungicides in mixtures: comparison of two methods for synergy calculation. EPPO Bull. 16:651-657.

Ling, K. S., Li, R., and Zhang, W. 2014. First report of Cucumber green mottle mosaic virus infecting greenhouse cucumber in Canada. Plant Dis. 98:701.

Liu, H. W., Luo, L. X., Li, J. Q., Liu, P. F., Chen, X. Y., and Hao, J. J. 2014. Pollen and seed transmission of Cucumber green mottle mosaic virus in cucumber. Plant Pathol. 63:72-77.

Lovisolo, O. 1980. Virus and viroid diseases of cucurbits. Acta Hortic.: 33-82.

Luo, Y., Morgan, D. P., and Michailides, T. J. 2001. Risk analysis of brown rot blossom blight of prune caused by Monilinia fructicola. Phytopathology 91: 759-768.

Malamy, J. 1992. Temperature-dependent induction of salicylic acid and its conjugates during the resistance response to Tobacco mosaic virus infection. Plant Cell Online 4:359-366.

Marçais, B., Piou, D., Dezette, D., and Desprez-loustau, M.-L. 2017. Can oak powdery mildew severity be explained by indirect effects of climate on the composition of the Erysiphe pathogenic complex? Phytopathology 107: 570-579.

Martin, F. N., and Loper, J. E. 2010. Soilborne plant diseases caused by Pythium spp.: Ecology, epidemiology, and prospects for biological control. Crit. Rev. Plant Sci. 18:111-181

Moreno, I. M., Thompson, J. R., and García-Arenal, F. 2004. Analysis of the systemic colonization of cucumber plants by Cucumber green mottle mosaic virus. J. Gen. Virol. 85:749-759.

Nitzany, F. E. 1966. Synergism between Pythium ultimum and cucumber mosaic virus. Phytopathology 56:1386-1389.

Nontajak, S., Vulyasevi, S., Jonglaekha, N., and Smitamana, P. 2014. Detection of Cucumber green mottle mosaic tobamovirus (CGMMV) in three growth stages of Japanese cucumber in the highland area of Northern Thailand. J. Agric. Technol. 10:277-287.

Park, S. M., Lee, J. S., Jegal, S., Jeon, B. Y., Jung, M., Park, Y. S., Han, S. L., Shin, Y. S., Her, N. H., Lee, J. H., Lee, M. Y., Ryu, K. H., Yang, S. G., and Harn, C. H. 2005. Transgenic watermelon rootstock resistant to CGMMV (Cucumber green mottle mosaic virus) infection. Plant Cell Rep. 24:350-356.

Patel, D., and Franklin, K. A. 2009. Temperature-regulation of plant architecture. Plant Signal. Behav. 4:577-579.

Pearson, M. N., Jackson, G. V. H., Pone, S. P., and Howitt, R. L. J. 1993. Vanilla viruses in the South Pacific. Plant Pathol. 42:127-131.

Philosoph, A. M., Dombrovsky, A., Elad, Y., Jaiswal, A. K., Koren, A., Lachman, O., and Frenkel, O. 2018. Combined infection with Cucumber green mottle mosaic virus and Pythium species causes extensive collapse in cucumber plants. Plant Dis. 102:753-759.

Reingold, V., Lachman, O., Belausov, E., Koren, A., Mor, N., and Dombrovsky, A. 2016. Epidemiological study of Cucumber green mottle mosaic virus in greenhouses enables reduction of disease damage in cucurbit production. Ann. Appl. Biol. 168:29-40.

Reingold, V., Lachman, O., Blaosov, E., and Dombrovsky, A. 2015. Seed disinfection treatments do not sufficiently eliminate the infectivity of Cucumber green mottle mosaic virus (CGMMV) on cucurbit seeds. Plant Pathol. 64:245-255.

Rosenzweig, C., Iglesias, A., Yang, X. B., Epstein, P. R., and Chivian, E. 2001 Climate change and extreme weather events: Implications for food production, plant diseases, and pests. Glob. Change Hum. Health 2:90-104.

Salvaudon, L., De Moraes, C. M., and Mescher, M. C. 2013. Outcomes of coinfection by two potyviruses: Implications for the evolution of manipulative strategies. Proc. R. Soc. B Biol. Sci. 280.

Schroeder, K. L., Martin, F. N., de Cock, A. W., Lévesque, C. A., Spies, C. F., Okubara, P. A., and Paulitz, T. C. 2013. Molecular detection and quantification of Pythium species-evolving taxonomy, new tools and challenges. Plant Dis. 97:4-20.

Shargil, D., Smith, E., Lachman, O., Reingold, V., Darzi, E., Tam, Y., and Dombrovsky, A. 2016. New weed hosts for Cucumber green mottle mosaic virus in wild Mediterranean vegetation. Eur. J. Plant Pathol. 148:473-480.

Soler-Aleixandre, S., López, C., Díez, M. J., Pérez De Castro, A., and Nuez, F. 2005. Association of Pepino mosaic virus with tomato collapse. J. Phytopathol. 153:464-469.

Stirling, G. R., Eden, L. M., and Ashley, M. G. 2004. Sudden wilt of capsicum in tropical and subtropical Australia: A severe form of Pythium root rot exacerbated by high soil temperatures. Australas. Plant Pathol. 33:357-366.

Sundheim, L., Brurberg, M., Hofsvang, T., Magnusson, C., Rafoss, T., Toppe, B . Tronsmo, A., and Økland, B. 2008. Pest risk assessment of the Cucumber green mottle mosaic virus in Norway. Norwegian Scientific Committee for Food Safety, Oslo, Norway.

Tesoriero, L. A., Chambers, G., Srivastava, M., Smith, S., Conde, B., and TranNguyen, L. T. T. 2015. First report of Cucumber green mottle mosaic virus in Australia. Australas. Plant Dis. Notes 11:1.

Thaler, J. S., Humphrey, P. T., and Whiteman, N. K. 2012. Evolution of jasmonate and salicylate signal crosstalk. Trends Plant Sci. 17:260-270.

Tian, T., Posis, K., Maroon-Lango, C. J., Mavrodieva, V., Haymes, S., Pitman, T. L., and Falk, B. W. 2014. First report of Cucumber green mottle mosaic virus on melon in the United States. Plant Dis. 98:1163.

Tollenaere, C., Lacombe, S., Wonni, I., Barro, M., Ndougonna, C., Gnacko, F., Sérémé, D., Jacobs, J. M., Hebrard, E., Cunnac, S., and Brugidou, C. 2017. Virus-bacteria rice co-infection in Africa: Field estimation, reciprocal effects, molecular mechanisms, and evolutionary implications. Front. Plant Sci. 8:645

Varveri, C., Vassilakos, N., and Bem, E. I. 2002. Characterization and detection of Cucumber green mottle mosaic virus in Greece. Phytoparasitica 30:493-501.

Vaumourin, E., and Laine, A. L. 2018. Role of temperature and coinfection in mediating pathogen life-history traits. Front. Plant Sci. 9:1670.

Watanabe, H., Kageyama, K., Taguchi, Y., Horinouchi, H., and Hyakumachi, M. 2008. Bait method to detect Pythium species that grow at high temperatures in hydroponic solutions. J. Gen. Plant Pathol. 74:417-424.

White, T. J., Bruns, T., Lee, S., and Taylor, J. W. 1990. Amplification and direct sequencing of fungal ribosomal RNA genes for phylogenetics. Pages 315-322 in: PCR Protocols: A guide to methods and applications. M. A. Innis, D. H. Gelfand, and J. J. Sninsky, eds. 678 Academic Press, New York.

Wu, H. J., Qin, B. X., Chen, H. Y., Peng, B., Cai, J. H., and Gu, Q. S. 2011. The rate of seed contamination and transmission of Cucumber green mottle mosaic virus in watermelon and melon. Sci. Agric. Sin. 44:1527-1532.

Yalpani, N., Silverman, P., Wilson, M. A., Kleier, D. A., and Raskin, I. 1991 Salicylic acid is a systemic signal and an inducer of pathogenesis-related proteins in virus-infected tobacco. Plant Cell 3:809-818.

Zhang, Y. J., Li, G. F., and Li, M. F. 2009. Occurrence of Cucumber green mottle mosaic virus on cucurbitaceous plants in China. Plant Dis. 93:200.

Zitter, T. A. 1995. Sudden wilt of melons from northern US perspective. Pages 44-47 in: Proc. Cucurbitaceae 94: Evaluation and Enhancement of Cucurbit Germplasm. G. E. Lester and J. R. Dunlap, eds. Gateway Printing, Edinburgh, TX

Zitter, T. A., Hopkins, D. L., and Thomas, C. E. 1996. Compendium of Cucurbit Diseases. American Phytopathological Society, St. Paul, MN. 